\title{
3. The Rise, Decline, and Reinforcement of the Crafts in the Service of the State
}

Historians' opinions are divided as to the usefulness of the classical pattern of ascent, flourishing, decay, and decline for the structural framework of analysis of political entities. In China, this had been a time-honoured concept applied to all dynastic histories. Yet it has been criticized because it focuses too much on the central government and is therefore not able to analyze socio-economic trends over periods that span several dynasties, most prominently the 'commercial revolutions' in the Song and the Ming. ${ }^{1}$

Nonetheless, since dynastic power did rise, flourish, and decline, this basic pattern for the shifts in power relations is certainly applicable to the core political decision-makers. This is especially so when it is combined with a complementary perspective on local and regional elites and bureaucracies, whose influence tends to increase after the central power has passed its apex. ${ }^{2}$ Naquin and Rawski have modified the paradigm with regard to the most influential networks or factions in the empire. In their three-phase model, imperial princes and Manchu institutions first wielded the greatest political power between 1644 and the 1730s; in the second phase, between the 1730 s and the 1820s, the official examinations for both Manchus and Chinese were the career path to highest political influence, and the most powerful institution in the central government was the Grand Council. During the third phase, lasting from 1820 to the end of the Qing dynasty, extrabureaucratic, intellectual networks and provincial administrators dominated, although at the top of the central government, Manchu control resurged. ${ }^{3}$ It was not embodied in the persons of the young or weak emperors Xianfeng, Tongzhi, Guangxu, and Puyi but by their regents: Empress Dowager Cixi, the mother of the Tongzhi and the aunt of the Guangxu emperors, Prince Gong (Yixin, 1840-1891), the brother of the Xianfeng emperor, and Zaifeng (1883-1851), the father of the last emperor Puyi.

In this sense, this could be considered dynastic decline if the power of the dynasty is associated only with the influence of the emperor. However,

1 Zurndorfer, 'A Guide to the "New" Chinese History', p. 184.

2 For a study of this phenomenon in the field of local and regional historiography, see Moll-

Murata, Die chinesische Regionalbeschreibung, esp. p. 239.

3 Naquin and Rawski, Chinese Society in the Eighteenth Century, pp. 52-53. 
if other powerful personalities from the imperial clan are considered, the downward trend was not that obvious. ${ }^{4}$

In regard to the financial strength of the Qing empire, the record is ambiguous. Naquin and Rawski maintain that in the eighteenth century, the Qing state collected a surplus in taxes, which amounted to 24 million tael in 1736 and was tripled by 1786 . However, the government also spent much of the revenues for warfare: 23 million tael for the conquest of Xinjiang $\left(1755^{-}\right.$ 1760 ), and three times as much for the campaigns in Jinchuan in Western Sichuan (1772-1776). In the 179os, for the first time the court did not have enough funds when it repressed the White Lotus rebellions. At one hundred million tael, it swallowed up more than 130 percent of the yearly income of the central government. Moreover, since 1840, indemnities demanded by the imperialist states put an extra strain on the budget of the Qing state. The additional tax charged since the suppression of the Taiping rebellion, lijin, remained in the provinces and thus could not help the financial situation of the central government. By 1900, the Chinese central government obtained less of the gross national product than in $1753 .{ }^{5}$

R. Bin Wong notes however that after the mid-nineteenth century, 'whatever the Qing state's weaknesses, raising money was not among them'. ${ }^{6} \mathrm{He}$ points to the capabilities of the Qing state to raise commercial taxes and especially customs revenues and quotes a figure of 49.5 million tael of revenue raised in 1849,77 percent of which came from agriculture and the rest from commerce. A total of 77 million tael was collected in 1885 due to a fourfold increase in commercial revenues. According to Wong, annual expenditures of the Qing ranged from 30 to 40 million tael between the 1720 s and the early 1840 and reached 70 to 80 million tael per year between the 1860 on and the early 1890 , while the gross income rose to as much as 302 million tael of revenue gathered in 1911, of which about 50 million came from agriculture, another 45 million from miscellaneous sources, and more than 207 million from commercial taxes. ${ }^{7}$

Moreover, whereas Naquin and Rawski point to the weakness of the military sector in the nineteenth century as well as the problem that since the Taiping rebellion the central government army was unable to maintain a military monopoly, ${ }^{8}$ Bin Wong emphasizes the successful suppression of the Taiping (1850-1864), Nian (1851-1868), and Muslim (1867-1873) rebellions

6 R. Bin Wong, China Transformed, p. 156.

7 Ibid., pp. 155-156.

8 Naquin and Rawski, Chinese Society in the Eighteenth Century, p. 219. 
and the fact that most of the regional armies that fought these rebels were demobilized in the 1870 . $^{9}$

In terms of the state's involvement in the economy, Naquin and Rawski mention the long-term trend away from mining and manufacturing, tea and salt production, domestic and foreign trade and claim that

The Qing state never reconciled the divergence between traditional notions of its proper economic function and its increasing impotence, nor did it evolve a new vision of its role in the economy. Until the last decade of its life, it preferred to try to preserve stability in the midst of change rather than to promote development. ${ }^{10}$

In their analysis, particularism existed in the economy and in the bureaucracy during the expanding commercialization, so that administrative responsibilities were assumed by private parties rather than public entities. ${ }^{11}$ This implied that the local elites took on many government functions, but it was only in the twentieth century that they turned their power against the state. ${ }^{12}$

On this point, Bin Wong maintains that the state could mobilize the funds to build up steamship lines and railways and not only heavy military industries but also light industries like textiles, thus expanding its range of activities in the late nineteenth century. ${ }^{13}$

These apparently conflicting views demonstrate that with regard to the state administration of craft manufacture, a general trend of retreat from direct management can be observed after activist beginnings. But in the final years of the dynasty, the commitment intensified once again and diversified into the promotion of manual trades as well as the introduction of mechanized production. In order to demonstrate this trend, the following sections outline the particular patterns of development in the main sectors of state engagement.

\section{The State Retires: Building Projects in the Nineteenth Century}

As shown in the preceding chapter, the number of permanent positions in the Bureau of Construction (yingshan si) of the Ministry of Public Works 
was not high and receded by almost half in the course of the dynasty. By contrast, in the palace the permanent positions for builders were almost tenfold that of the Ministry and were reduced by only eleven percent. For building, the workforce was usually hired in temporary assignments. After 1860, the names of the construction companies and even the individual owners of these companies begin to appear in estimates and various types of communications in archival materials or the documentation of particular projects. For instance, in the $1872-1873$ reconstruction project for the country palace Yuanming yuan, which in 1860 had been destroyed by English and French troops in the wake of the Second Opium War, seven firms and their owners were named in the archival documents of the Imperial Household Department. The project was broken off due to a lack of funds, little support from political decision-makers, and the difficulty in acquiring the necessary timber. ${ }^{14}$ The task of the building firms in this project was to contract labour (baogong) and provide less costly building materials. ${ }^{15} \mathrm{~A}$ case that nevertheless shows the interaction of government officials and a private craftsperson and building contractor occurred during the construction of the mausoleum for the Xianfeng emperor, Dingling, in 1874. Guo Fenglin, the owner of the timber yard and carpentry shop Xianghe muchang in Peking, had clashed and verbally abused a Section Director about the payment of compensation for repairing a pavilion built over a well that had collapsed within the warranty time. ${ }^{16}$ This act of insubordination, which caused considerable commotion and paperwork, shows the self-assertion of the concerned person who maintained, certainly in order to stress his probity and status, that he had previously donated money to the state and acquired the official title of baoshou be $i$ 保 守備 (defender-in-attendance). ${ }^{17}$ Guo and other owners of timber yards and construction firms ${ }^{18}$ are referred to in the late Qing documents as shangren. As ordinary workmen or masters (jiang), they would hardly have been acceptable as business partners in official work projects.

With regard to the production of building materials, the imperial kilns may serve as an example. As both Zhu Cishou and Xu Jianqing have pointed out, the Qing dynasty operated fewer kilns for baking bricks and tiles than the Ming dynasty. The three centres were the Liuli chang (Glazed Tile

16 Gongcheng beiyao, chap. 7, pp. 1-18. The entire chapter is dedicated to the incident. The sum in question was 450 tael.

17 Ibid., chap. 7, p. 15 .

18 For instance, the owners of the timber yards Tianlin muchang 天林木廠 and Tianquan muchang 天泉木厰 in Peking who renovated the official mint Baoyuan ju in 1902. 
Manufactory) in Peking, which was used continuously until 1825 and then relocated to the Western Hills near Peking; the brick manufactories in Linqing and Shandong; and the Suzhou Metal Tile Manufactory (Jinzhuan chang). ${ }^{19}$ The Liuli chang Manufactory was supervised by one Han and one Manchu official, but apparently from early on, the operational risk was outsourced to so-called 'kiln households' (yaohu), which are mentioned since 1694. These brick bakers also had to pay a land tax for the plots where their kilns were situated. Therefore this can hardly have been an imperial manufactory but rather subcontracted workshops that supplied the state. ${ }^{20}$ The other two sites were activated in case of large building projects but not permanently run, and were no longer used after the Daoguang reign. ${ }^{21} \mathrm{Xu}$ Jianqing refers to Suzhou brickmakers who obtained their food rations even if the kilns were not in operation. She suggests that this applied also to other government workshops and manufactories, such as the silk weavers in Jiangnan, the porcelain potters in Jingdezhen, and the shipbuilders in Fujian and Hangzhou. ${ }^{22}$

Thus, although official building projects were directed and administered by the state, they required a considerable standing workforce for palace buildings only. For buildings outside the palace and also within the palace precincts (if a larger workforce was required), workers were hired by means of a contractual system. The building materials for the state were not permanently kept on stock but provided from the market in the case of timber and in a kind of subcontracting system for bricks.

\section{The Three Silk Weaveries in Jiangnan}

The state weaving manufactories in the Lower Yangzi region, the Jiangnan san zhizao ju, located in Suzhou, Nanjing, and Hangzhou, were revived in the first years of the Qing rule after they had been closed down at the end of the Ming dynasty. ${ }^{23}$ Their responsibility was to reel the silk, to dye, to weave, and partly to embroider the fabrics used at court and for high

19 Zhu Cishou, Zhongguo gudai gongye shi, pp. 789-79o, Xu Jianqing, Qingdai qianqi, p. 329. Kerr et al., Ceramic Technology, p. 516, point out that the Suzhou tiles were referred to as 'metal tiles' for the metallic sound they emitted when struck. Their colour was actually black.

20 Xu Jianqing, Qingdai qianqi, pp. 329-330.

21 Ibid., p. 328.

22 Ibid., p. 334.

23 For the scope of production of the Ming state weaveries, see Schäfer and Kuhn, Weaving an economic pattern in Ming times. These authors date the interruption of state silk production during the Ming-Qing transition from 1628 to 1645 (p. 56). 
officials as well as the textiles used as gifts from the emperor to officials or emissaries from tributary states. ${ }^{24}$

In relation to their size in the Ming dynasty, the three weaveries were enlarged so that the number of looms as well as artisans was more than doubled. In the first decades of the Qing, these vacancies could not be filled, so that by 1667 , in Suzhou 170 looms were missing. ${ }^{25}$ The actual figure of 800 looms was probably reached around 1686. Furthermore, a system of outsourcing in silk weaving seems to have applied, at least in certain phases and for certain parts of the production. This was the so-called lingzhi ('weaving to order') system, in which the authorities gave out licenses to the weaving households for subcontracting people to weave in the manufactory. ${ }^{26}$ The system was inherited from the Ming. After initial confusion in the early years of the Qing, the practice emerged that the state provided the materials and paid the artisans monetary wages and food rations. They had the status of official artisans and worked in the government weaveries under strict supervision and discipline. ${ }^{27}$

Table 16 The norm quotas of looms and artisans at the Three Silk Weaveries in the early and mid-Qing

\begin{tabular}{lcccc}
\hline & Number of looms & & $\begin{array}{c}\text { Number of } \\
\text { artisans }\end{array}$ \\
\hline Location & Period Early Qing, [ca. 1686] & $\mathbf{1 7 2 5}$ & $\mathbf{1 7 4 5}$ & $\mathbf{1 7 4 5}$ \\
\hline Nanjing & 538 & 557 & 600 & 2,550 \\
Suzhou & 800 & 710 & 663 & 2,175 \\
Hangzhou & 770 & 750 & 600 & 2,330 \\
Total & 2,108 & 2,017 & 1,836 & 7,055 \\
\hline
\end{tabular}

Sources: Fang Xing et al., 'Silk Weaving in Jiangsu and Zhejiang', p. 206, and Peng Zeyi, 'Qingdai qianqi', p. 99.

In relation to the private weaveries, the total number of looms and people employed in the three silk weaveries in the mid-eighteenth century (about 7,00o) was not large. According to Zhu Cishou, in the Qianlong and Jiaqing reigns, the aggregate number of satin (duan) looms in Nanjing was as high as 30,000. Private weaveries in Suzhou had a total number of 10,000 looms and 
340 dyeing workshops, and the private weaveries in the city of Hangzhou had about 3,00o looms. ${ }^{28}$ The looms of the Imperial Weavery in Nanjing thus amounted to only two percent of those of the private weaveries. For Suzhou this figure was six percent, and for Hangzhou twenty percent. Other estimates give even higher figures for the private looms. ${ }^{29}$

In the Taiping rebellion, all of the three weaveries were badly damaged. They were rebuilt in the Tongzhi reign (1864-1872), but thereafter operated only at a reduced level with about one-third of the original looms and artisans..$^{30}$ For 1870 , Shih Min-hsiung quotes figures of about 600 looms in Nanjing, 240 in Suzhou, and 122 in Hangzhou. ${ }^{31}$ The weavery in Nanjing was dissolved in 1904 because it seemed uneconomic to have two imperial workshops, Suzhou and Nanjing, in one province. ${ }^{32}$ The main reasons for the decline may have been less demand from the court and the high prices for raw silk, which had doubled since the post-Taiping period. ${ }^{33} \mathrm{Xu}$ Jianqing points to the fact that after the Taiping period, the court turned to the commercial market for its needs. In the case of satin from Nanjing, the percentage of the weaves bought from private producers amounted to up to 80 percent. ${ }^{34}$

\section{'Prosperity is not on the wane':35 The Jingdezhen Porcelain Manufactory}

The market town of Jingdezhen was founded in the first year of the Jingde era in the Northern Song (1004) and from early on produced 'real' porcelain, in contrast to the earthenware produced by other Southern Song centres of ceramic production. ${ }^{36}$ Porcelain, similar to tea, was sent to the court as

28 Zhu Cishou, Zhongguo gudai gongye shi, p. 789 .

29 Fang Xing et al., 'Silk Weaving in Jiangsu and Zhejiang', p. 207, assume an aggregate number of 8o,ooo looms in the two provinces Zhejiang and Jiangsu.

30 Xu Jianqing, Qingdai qianqi, p. 324.

31 Shih Min-hsiung, The Silk Industry in Ch'ing China, p. 47.

32 Peng Zeyi, Zhongguo jindai shougongye, vol. 2, p. 504, quoting from Donghua xulu 東華續 錄 for the year Guangxu 30 (1904).

33 Shih Min-hsiung, The Silk Industry in Ch'ing China, pp. 47-49. Shih dates the closure to 1894, but this is not corroborated by the three sources cited by Peng Zeyi.

34 Xu Jianqing, Qingdai qianqi, p. 324.

35 This was the impression of an English traveller to Jingdezhen, Mr. Drew, in 1869. Decennial Reports, 1882-1891, p. 205.

36 Definitions for 'porcelain' vary in China and the West. Traditionally, in the West, transparency is the criterion for deciding whether a piece of ceramic constitutes porcelain; in China the clear sound coming forth from pieces of porcelain struck against each other serves as distinctive feature for $c i$ 瓷 as opposed to the earthenware tao 陶. Rose Kerr et al. quote the modern definition 
'tribute', a kind of natural tax, and the quality of the items was controlled by government officials. ${ }^{37}$ Yet it was only in the Ming dynasty that a completely state-run government manufactory with kilns was established. ${ }^{3}$ From this time on, the local Jingdezhen ware was referred to as 'official ware' guanyao. The imperial manufactory first operated 20 kilns, then $5^{8}$ in the Xuande reign (1425-1436) ${ }^{39}$ - each for different kinds of wares - and 23 specialized workshops for the particular steps of production. In the Zhengde and Jiajing reigns (1505-1566), 300 craftsmen including masons, carpenters, and blacksmiths were employed in addition to hired labour. ${ }^{40}$ Another source refers to 500 craftsmen and over 1,000 labourers at the imperial kilns during the Jiajing reign. ${ }^{41}$ At the same time, private kilns also flourished. Porcelain was being made in five or six other locations in the Ming empire, but the official manufactory and the private enterprises at Jingdezhen had become the centre of the industry. According to the technical compendium Tiangong kaiwu ('The exploitation of the works of nature', 1637), by the end of the dynasty Jingdezhen produced more than all other regions put together. ${ }^{42}$ The imperial manufactory continued to produce until 1608.43

In the Qing dynasty, the imperial manufactory and kilns were reopened on the original site in $1654^{44}$ and refurbished in 1680 . They flourished for about one hundred years under the direction of official commissioners sent from

'a vitrified, white, and translucent ware --- that is fired at $1,300^{\circ} \mathrm{C}$ plus' (Kerr et al., Ceramic Technology, p. 9, from Hamer \& Hamer, The Potter's Dictionary of Materials and Techniques 1975, p. 229) but qualify this by noting that Chinese porcelain was not necessarily white or translucent, and it was fired at temperatures between 1,150 and $1,400^{\circ} \mathrm{C}$. In Kerr's view, porcelain was not 'invented' but rather 'discovered' or, more accurately, it 'emerged' in China when potters in the north experimented with whiter materials and higher kiln temperatures. Scholarly opinions on the earliest specimens of 'real' porcelain vary. Kerr and colleagues consider that 'the world's first true porcelains' were the Xing wares made in Hebei province during the early Tang dynasty (Kerr et al., Ceramic Technology, pp. 151-152).

37 Kerr et al., Ceramic Technology, pp. 185-186.

38 The founding date is disputed. Some authors assume that the year 1369 (Sayer [transl.], Ching-te-chen t'ao-lu, p. 41) is correct. Others, as in Jingdezhen taoci shigao, pp. 96-97, doubt that a manufactory could have been built as early as that, just after the rise of the Ming, and suggest the year 1402 instead. For further discussion, see also Kerr et al., Ceramic Technology, p. 186 , fn. 273 .

39 Sayer (transl.), Ching-te-chen t'ao-lu, p. 41.

40 Fang Zhuofen et al., 'The Porcelain Industry of Jingdezhen', p. 311, Zhongguo taoci shi, p. 366, quoting from Jiangxi da zhi 江西大志, 'Taoshu' 陶書.

41 Jiangxi tongzhi (1881), chap. 93, fol. 9a, Memorial by Xu Zhi.

42 Xu Jianqing, Qingdai qianqi, p. 557; Fang Zhuofen et al., 'The Porcelain Industry of Jingdezhen', p. 309, both referring to Song Yingxing, Tiangong kaiwu, chap. 2.

43 Kerr et al., Ceramic Technology, p. 188.

44 Jiangxi sheng tongzhi, chap. 93, fol. 7 a. 
Peking. The manufacturing and despatch of porcelain was arranged by the Palace Workshops ([Yangxin dian] zaoban chu) of the Imperial Household Department. The workshops would send order lists and models to the manufactory that would be produced under the supervision of the superintendent's assistant in Jingdezhen. After control by the resident superintendent, who often also oversaw the customs affairs of the region, the finished porcelain in standard and substandard quality would be shipped to Peking. ${ }^{45}$ In the palace, the porcelain was received in the porcelain storehouse, $c i k u$, of the Imperial Household Department. ${ }^{46}$

The number of craft specialisations in the imperial manufactory is given as 23, as in the Ming, and the number of kilns as six, each for a specific type of vessel. It is disputed whether facilities of this limited size could produce the output stated for the Yongzheng and Qianlong eras. ${ }^{47} \mathrm{Lu}$ Jiaming, referring to the 'Record on Porcelain in Jingdezhen' (Jingdezhen taolu, 1815), argues that from the early eighteenth century on, the late Ming method of forming and painting in the imperial manufactory and firing in private kilns must have been reintroduced. ${ }^{48}$ Yet during the Qing, the practice was managed more efficiently than in the Ming, so that the kiln owners did not take the risk alone. ${ }^{49}$ After the reconstruction in 1866 , only low temperature muffle furnaces for firing overglaze ornamentation remained in use in the imperial manufactory..$^{0}$

The superintendents of the early and mid-eighteenth century became famous because of their achievements in quality improvements, so that the wares produced during their terms of office were given their names. We thus know of 'Lang ware' after Lang Tingji, superintendent from 1705 to 1712; 'Nian ware' after Nian Xiyao, superintendent from 1726 to 1735; and most illustrious

45 Kerr et al., Ceramic Technology, p. 201.

46 The porcelain chamber belonged to one of the Six Storehouses liu ku 六庫of the Grand Storage office guangchu si. Besides 'old and new porcelain', gold, silver, enamel, inlay, bronze, and tin dishes and vessels were accumulated there. See Zongguan neiwufuxianxing zeli, 'Guangchu si', chap. 1, p. $35^{2}$.

47 Fang Zhuofen et al., 'The Porcelain Industry of Jingdezhen', p. 312, Lu Jiaming, 'Ming Qing shiqi Jingdezhen yuqichang', p. 32 .

48 Lu Jiaming, 'Ming Qing shiqi Jingdezhen yuqichang', p. 31, see Jingdezhen taolu tushuo, chap. 10, p. 261: 国朝初燒造龍缸未成, 至唐窯始復其制, 搭民官燒。[... 然今則敞器盡搭燒 民窯, 照數給置, 無役派賠累也, (transl. Sayer) p. 112: 'In the beginning of the present dynasty they [the palace factory] failed to make dragon jars, and it was not until T'ang Ying's time that they resumed their manufacture using private kilns for that purpose. [...] To-day the palace articles are entirely farmed out to private kilns, payment being made according to the numbers to be baked, and the losses incurred by the default of the workmen do not fall upon them.'

49 Kerr et al., Ceramic Technology, p. 200.

$5^{0}$ Kerr et al., Ceramic Technology, p. 200. 
of all, 'Tang ware' after Tang Ying (1682-1756),,$^{11}$ Nian Xiyao's assistant since 1728 and superintendent between 1736 and 1756 . Lao Ge, the assistant to Tang and succeeding superintendents from 1741 to 1768 , maintained the high quality standards after Tang Ying's death, but after Lao Ge's own retirement, artistic standards are said to have not reached the same level again..$^{2}$ From 1787 onwards, the connection to the central government and the Imperial Household Department seems to have become looser, so that together with the director of the nearest customs station on the Yangzi River, Jiujiang, who previously had also been in charge, ${ }^{53}$ regional administrators took over the responsibility for the imperial manufactory. ${ }^{54}$ In the attacks by Taiping troops and counterattacks by the government army between 1854 and 1864, the manufactory was destroyed and the workforce scattered.

The manufactory was rebuilt in 1866 on a larger scale than before. ${ }^{55}$ Reports on the period between 1866 and 1910 are relatively scarce. Most documents recording the despatch to Peking at the Jiujiang customs station are extant..$^{6}$ Based on these, Liang Miaotai has set up a statistical table of the production volume and the expenses in the last years of the Qing. Production figures are reported until 1908 and expenses until $1910 .{ }^{57}$ At a yearly average of 22,000 pieces of first-grade (shangse) and second-grade (cise) quality, the production was not much lower than in the best years of Qianlong, when the respective norm figures were 29,000 pieces. ${ }^{8}$ However, concerning the quality norms set by the government, first-grade pieces according to the 1743 norm figures were acceptable in a range of $62-65$ percent, and second-grade pieces between 35 and 38 percent. Up to 20 percent of kiln wasters (that is, misfired pieces) were allowed. ${ }^{59}$ Between 1866 and 1908, the factual figures were 30 percent first-grade and 70 percent second-grade pieces, and a percentage of 18 for

$5^{1}$ For biographical information, see Hummel (ed.), Eminent Chinese of the Ch'ing Period, p. 442.

$5^{2}$ Kerr et al., Ceramic Technology, p. 27.

53 Fu and Zhen, 'Tang Ying nianpu', state that Tang Ying directed the Jiujiang customs and worked concurrently as the Director of the Imperial Manufactory from 1739. He would spend half a month during the firing periods in spring and in autumn at the Manufactory. According to Zhu Shan, 'Taoci shi shang bei yiwang de ren', pp. 36-37, it was Lao Ge who stayed in Jingdezhen continuously as deputy director during Tang's absences in Jiujiang.

54 Kerr et al., Ceramic Technology, p. 188; Jiangxi tongzhi, chap. 93, fol. 8a.

55 Lu Jiaming, 'Ming Qing shiqi Jingdezhen yuqichang', p. 32. Jiangxi tongzhi, chap. 93, fol. 8 a.

56 However, at the First Historical Archives in Peking they were 'lent out for publication' in 2006.

57 Liang Miaotai, Ming Qing Jingdezhen, pp. 112-113.

$5^{8}$ Tang Ying ji, 'Taocheng jishi' 陶成紀事 (Record of facts about porcelain production), p. 950, also quoted by Lan Pu in Jingdezhen taolu tushuo, p. 62, (transl. Sayer) p. 12.

59 Tang Ying ji, 'Taocheng jishi', p. $95^{\circ}$. 
wasters. Liang Miaotai's table of expenses shows that the court in the late Qing period spent considerable amounts for porcelain: for the despatches between 1870 to 1910 , this totaled 975,470 tael or an average of ca. 25,000 tael per year. ${ }^{60}$ By comparison, the highest norms in the two hundred years before the Opium War were set at 10,00o tael per year in $1739 .^{61}$

Therefore, it can hardly be argued that the imperial porcelain manufactory at Jingdezhen experienced a marked economic decline in the last fifty years of the dynasty, even if the firing process was outsourced to private kilns. Regarding the wares produced in the Tongzhi reign (1862-1874), a Dutch porcelain expert concludes that the late Qing potters 'hadn't lost their skills' ${ }^{6}{ }^{2}$

As in silk weaving, the quality of the porcelain from the imperial manufactory was arguably the highest and set the standard for the commercial market, ${ }^{63}$ and again as in silk weaving, the commercial market had a far bigger output than the imperial manufactory. Since systematic and long-term data are missing for the private sector, its production can only be estimated on the basis of reported numbers and the firing capacities of kilns. Fang Zhuofen and colleagues point out that the total output of Jingdezhen porcelain in the early Qing has been calculated on the basis of the consumption of firewood at about 200,000 $\mathrm{dan}^{64}$ or 40 million pieces per year, but they assume that for the Qianlong reign, the figure must have been about 300,000 dan or 60 million pieces a year. The maximum - but not undisputed - quota for imperial porcelain was 'several hundred thousand pieces'. ${ }^{65}$ If this implies about 500,000 pieces, then the imperial porcelain amounted to about 0.8 percent of the private production at its most active period. ${ }^{66}$

The manufactory was closed down in 1910 and succeeded by the Jiangxi Porcelain Company (Jiangxi ciye gongsi) that operated partly with

6o Liang Miaotai, Ming Qing Jingdezhen, pp. 123-126. Two years were not included in this account.

61 Ibid., p. 120, 129.

62 Nanne Ottema, Chineesche Ceramiek, p. 233.

63 Since official production was fired at private kilns, some was illegally appropriated from there. For the faking of the marks on imperial wares, see Liang Miaotai, Ming QingJingdezhen, p. 138. The kiln wasters were either sent to Peking for sale, or they were sold on site. See Kerr et al., Ceramic Technology, pp. 200-201.

64 dan 擔 is the unit for a kiln load of 200 porcelain pieces.

65 Tang Ying ji, p. 144 (Preface to the gazetteer of Fuliang, the district where the market town Jingdezhen was situated, Fuliang xianzhi 浮梁縣志, dated 1740). However, this figure has been doubted by Lu Jiaming, 'Ming Qing shiqi Jingdezhen yuqichang', p. 32, who supposes that it spans several years, since Tang Ying in 1743 reported the quota of a maximum of 29,00o pieces per year.

66 Fang Zhuofen et al., 'The Porcelain Industry of Jingdezhen', p. 314. 
government funds from the provinces of Hebei, Hubei, Jiangsu, Anhui, and Jiangxi and partly with private capital. ${ }^{67}$

\section{Patterns of Development and Decline}

The three sectors outlined above show how the state withdrew from the organization of craft production in varying degrees and for different reasons.

In building, the system of cooperation with local building companies and timber merchants who were employed especially for recruiting the workforce is evident for the later phases. State administration still controlled all accounting procedures, the allocation of building materials, and the progress and execution of the work. For glazed tiles and bricks, sub-contractors worked on demand, while timber was allocated from the market.

Silk weaving is a clear case in point of Xu Jianqing's model of state engagement in the crafts, according to which the state at first organized and financed craft branches in which the private sector could not supply its needs but later retired from the active organization of weaveries and relied on the commercial sector for its silk textiles. ${ }^{68}$

In the manufacturing of porcelain, the output of the state workshops was also extremely small but was leading in design and workmanship. Since forming and firing are such distinct phases of the working process that require very different equipment and skills, kiln work could be outsourced from early on, but forming and decoration remained within the imperial porcelain manufactory. The 'decline' of the official sector is therefore less marked than in the silk weaving sector.

In the two sectors of luxury production, silk weaving and porcelain manufacture, the state did not produce for profit, although in the case of porcelain, kiln wasters or at times second-grade porcelain were sold on the open market and thus could make up for some of the production costs. In the late nineteenth century, the costs for silk weaves for the use of the court were lower if bought from commercial producers than those produced at the state manufactories. What is the reason, then, that the government maintained the craft production almost to the end of the dynasty? For porcelain, it has been plausibly argued that the main reason for this was that imperial patterns

67 Kerr et al., Ceramic Technology, p. 188; Jiangxi sheng qinggongye ting (ed.),Jingdezhen taoci shigao, p. 270.

68 Xu Jianqing, Qingdai qianqi, p. 554. 
had to be preserved ${ }^{69}$ For silk weaving, Paolo Santangelo explains that the manufactories were not economic enterprises but political and organizational centres. Since they came under the supervision of high-ranking bondservants from the Imperial Household Department whose relationship to the emperor was particularly close, they can be understood as a representation of the court in the most affluent region of the empire that lay far away from Peking. Especially in the early Qing, the supervisors of the Nanjing and Suzhou weaveries often informed the emperors about the political and economic situation in Jiangnan..$^{0}$ Moreover, they also organized the acquisition of various objects produced in the region - not only silk weaves..$^{71}$ Although the informal services for the emperor were no longer required in the late Qing, reports about silk prices and the labour market were regularly delivered also in this period. The Jingdezhen manufactory did not have the same politically and economically essential functions as the weaving manufactories.

As the three samples show, the reasons for state engagement or retreat were complex and pertained to local political situations and the nature of the commodity that was being produced.

The following chapters present investigations on two craft branches that do not belong to the field of luxury production but were of strategic importance for two fundamental tasks of the Qing state: security and information. Shipbuilding in the military field served to defend China's sea frontier and to transport grain provisions for the court and the army. Printing produced the texts used for the legitimation of the Qing state, the education and civilization of its subjects, and the dissemination of information to its officials. Both branches of production belong to the complementary fields to which the self-strengthening effort of the nineteenth century was devoted: the preservation of the Chinese 'cultural essence' (tiyong) and the application of modern Western techniques.

These two craft branches will be treated in more detail because it was in these branches that mechanization and technology transfer were actively realized by central and local governments at an earlier date than in the other sectors. Thus they exemplified a particular dynamism in times of crisis.

69 Lu Jiaming, 'Ming Qing shiqi Jingdezhen yuqichang', p. 32.

70 Santangelo, 'The Imperial Factories of Suzhou', p. 285.

71 Among the documents concerning the Suzhou weaving manufactory in the First Historical Archives, Peking, we found, for instance, the production prices of white jade bowls. The jade carvers earned the palace standard wage of 0.154 tael per day. First Historical Archives, Neiwufu tang qingce 内務府堂清冊, Gongye 工業, nos. 94 and 106 from 1770 and 1775; a late document from 1884 records the purchase of bamboo items. Neiwufu tang qingce, Gongye 273, Su[zhou] 蘇 226 for a purchase in 1884 . 
